\title{
THE YARMOUTH DRUMLIN FIELD, NOVA SCOTIA, CANADA
}

\author{
By C. P. Gravenor
}

(Department of Geology, University of Windsor, Windsor I I, Ontario $\mathrm{NgB}_{3} \mathrm{P}_{4}$, Canada)

\begin{abstract}
The Yarmouth drumlinized area is a relatively small field of about 150 drumlins located south and south-east of the town of Yarmouth, Nova Scotia. An analysis of the drumlin shapes indicates that in the majority of cases the stoss end is on the southern extremity of the drumlin. This would suggest that the ice moved in from the south, a concept which is contradictory to pebble lithology and fabric analysis of the till in the drumlins and surrounding ground moraine. The drumlin field is anomalous in other respects in that the drumlin density is very low compared with other fields, and granulometric analysis shows that the drumlins are composed of coarse-grained material with only minor amounts of clay.

It is suggested that the drumlins were originally formed by south to south-easterly flowing ice but during a later phase of glaciation a local centre of outflow, probably short-lived, developed south of Yarmouth on the continental shelf, and the drumlins were reshaped by ice flowing toward the north prior to the disappearance of this centre. Thus this area of drumlins was presumably not affected by the later area of outflow centred on the interior upland of western Nova Scotia which was hitherto believed to account for the Yarmouth drumlins.

RÉsumé. Le champ de drumlin de Yarmouth, Nouvelle Écosse, Canada. La zone de drumlin de Yarmouth est un champ relativement petit d'environ 150 drumlins, localisés au Sud et au Sud-Est de la ville de Yarmouth en Nouvelle Écosse. Une analyse de la forme des drumlins indique que dans la majorité des cas, le gros bout est à l'extrémité Sud du drumlin. Ceci suggèrerait que la glace se déplaçait en venant du Sud; une hypothèse qui est en contradiction avec la composition lithologique des cailloux et l'analyse de l'origine des dépôts dans les drumlins et dans la moraine de fond environnante. Le champ de drumlins est anormal à d'autres égards, en ce que la densité des drumlins est très faible en comparaison d'autres champs, et l'analyse granulométrique montre que les drumlins sont composés de matériel à grains grossiers avec seulement une faible proportion d'argile.

On suggère que les drumlins furent à l'origine, formés par de la glace coulant vers le Sud-Est; mais au cours d'une phase ultérieure de la glaciation, un centre local d'écoulement, probablement de courte durée, se développa au Sud de Yarmouth sur la calotte continentale et les drumlins furent refaçonnés par de la glace s'écoulant vers le Nord, avant la disparition de ce centre. Par conséquent, on présume que cette zone de drumlins ne fut pas affectée par l'écoulement qui fut centré plus tard sur le plateau intérieur de la Nouvelle Écosse occidentale et que l'on croyait jusqu'ici être en cause dans la formation des drumlins de Yarmouth.

Zusammenfassung. Das Drumlinfeld von Yarmouth, Nova Scotia, Kanada. Das Drumlingebiet von Yarmouth ist ein verhältnismässig kleines Feld mit ungefähr 150 Drumlins, das im Süden und Südosten der Stadt Yarmouth, Nova Scotia, liegt. Eine Untersuchung der Drumlinformen zeigt, dass in den meisten Fällen das Stossende der Drumlins nach Süden weist. Dies würde darauf hindeuten, dass das Eis von Süden einfloss, ein Konzept, das zur Kieslithologie und zur Strukturanalyse der Geschiebe in den Drumlins und in der umgebenden Grundmoräne im Widerspruch steht. Das Drumlinfeld ist auch in anderer Hinsicht ungewöhnlich: Die Drumlindichte ist im Vergleich zu anderen Drumlinfeldern sehr gering und eine Kernanalyse zeigt, dass sich die Drumlins aus grobkörnigem Material mit nur geringen Lehmanteilen zusammensetzen.

Es wird vermutet, dass die Drumlins ursprünglich von Eis gebildet wurden, das nach Süden bis Südosten strömte. Aber während einer späteren Vergletscherungsphase entwickelte sich auf dem Kontinentalschelf südlich von Yarmouth ein - wahrscheinlich kurzlebiges - lokales Ausflusszentrum, von dem aus die Drumlins bis zu seinem Verschwinden durch nach Norden fliessendes Eis umgestaltet wurden. So wurde dieses Drumlingebiet vermutlich nicht von dem späteren Ausflussgebiet beeinflusst, dessen Zentrum im inneren Hochland von West-Nova Scotia lag und dem bisher die Entstehung der Yarmouth-Drumlins zugeschrieben wurde.
\end{abstract}

\section{INTRODUCTION}

The Yarmouth drumlin field is located on the south-western end of the Nova Scotia peninsula, south and south-east of the town of Yarmouth (lat. $43^{\circ} 50^{\prime} \mathrm{N}$., long. $66^{\circ}$ ro $^{\prime} \mathrm{W}$.). In contrast to other drumlinized areas, the Yarmouth field is relatively small, containing about 150 drumlins in an area of about $730 \mathrm{~km}^{2}$. Many of the drumlins form islands in the Atlantic Ocean and have been eroded on their south and west sides by wave and tidal action. This erosion has exposed fresh surfaces of till which afford the opportunity to examine the internal nature of the drumlins. 
The bedrock of the region has been mapped by Taylor (1967) and apart from some andesite, slate and schist in the immediate vicinity of the town of Yarmouth, most of the area is underlain by greywacke, argillite, slate and siltstone (and metamorphosed equivalents) of the Meguma Group which is Ordovician or earlier in age. Granites of Devonian age intruded the rocks of the Meguma Group on the peninsula about $2.4 \mathrm{~km}$ east of Reef Island (Fig. I).

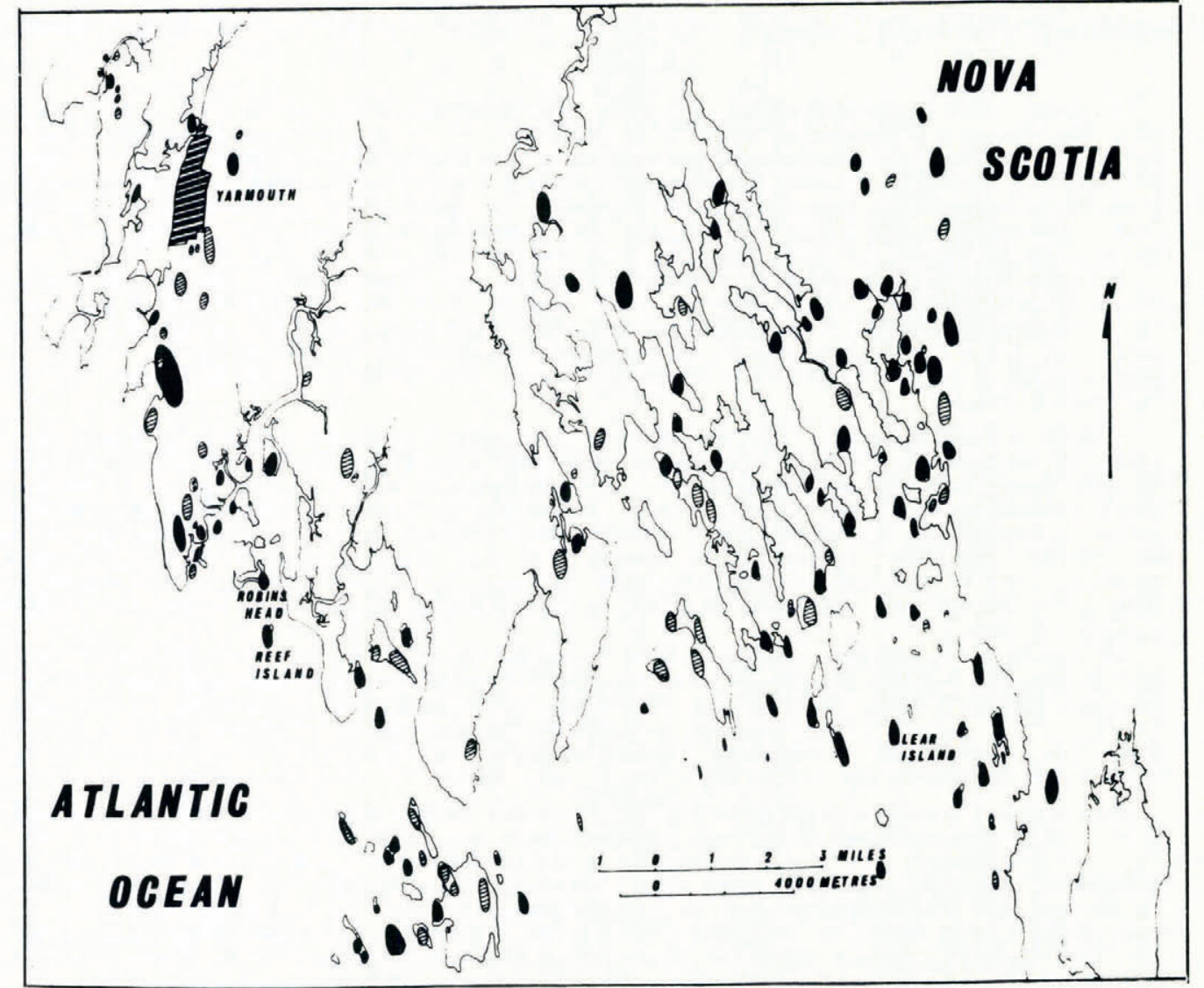

Fig. I. Map of the Yarmouth drumlin field. The drumlins marked solid have their stoss end at the south; the cross-hatched drumlins are elliptical in shape and those marked with crosses have the stoss end to the north.

The pebble lithology of the till in the Yarmouth area has been examined by Grant (unpublished), who found that the pebble assemblage is composed primarily of quartzite, slate and schist of the Meguma Group, with minor amounts of granite and volcanics derived from the New Brunswick Highlands and the south shore of the Bay of Fundy, respectively. This pebble lithology clearly demonstrates that at one stage in the glacial history of the area the ice moved in a southerly direction.

The drumlins of south-east Nova Scotia have been described by Goldthwait (1924) and Wilson (1938), who noted that the large drumlin field near Lunenberg, Nova Scotia, as well as the Yarmouth field, are both underlain by slate, and they concluded that the slate is essential to provide clay for the formation of the drumlins. More recently, Grant (unpublished) has shown that the Lunenberg drumlins are not derived from slates but are composed of red clay till derived from Carboniferous rocks. 
The latest glacial events in the Maritimes have been described in a series of papers by Prest and Grant (e.g. Prest and Grant, I969; Grant, I97 [a], [b], I972). The ice directions proposed by Prest and Grant for the Yarmouth area show a flow from the north across the west end of the Nova Scotia peninsula and terminating in the Atlantic Ocean south of the present southern shoreline of Nova Scotia.

\section{SiZE AND DISTRIBUTION OF THE DRUMLINS}

The distribution of drumlins in the Yarmouth field is shown on Figure 1. The orientation of the long axes of the drumlins varies considerably from one drumlin to the next but the average for the field is about $10^{\circ}$ west of north. The maximum length is $1800 \mathrm{~m}$ and the minimum is $200 \mathrm{~m}$, with a mean of about $800 \mathrm{~m}$. Widths vary considerably with a maximum of $700 \mathrm{~m}$ to a minimum of $100 \mathrm{~m}$ and a mean of about $350 \mathrm{~m}$. Their height varies from 8 to $30 \mathrm{~m}$ with a mean of about $18 \mathrm{~m}$. This size range of the drumlins is very similar to that given by Wilson (1938) for the large field of drumlins in the Lunenberg area of south-central Nova Scotia.

As mentioned above, there are about $\mathrm{I} 50$ drumlins in an area of about $750 \mathrm{~km}^{2}$, which gives an average density of about one drumlin per $5 \mathrm{~km}^{2}$. This is a very low density compared with other drumlin areas (Doornkamp and King, I97I, p. 295) and may be explained by the fact that there is a large area south-east of the town of Yarmouth which contains no drumlins (Fig. I), and also the possibility that many of the drumlins in the offshore area are either below sea-level or their tops have been removed by erosion. In other words, it is difficult to draw a meaningful boundary around the field to provide accurate dimensions of the drumlin area. Therefore, in order to obtain a more accurate figure for comparison purposes with other drumlin fields, a part of the eastern section of the drumlin field was selected and divided into 6o squares measuring $2.25 \mathrm{~km}$ on each side of the squares according to the method described by Doornkamp and King (1971, p. 294-98).

The results of this study showed that there are 96 drumlins in 60 squares for a mean frequency of I.6 drumlins per square, which is still very low compared with the densities reported for three drumlinized areas by Doornkamp and King (I97I). A $\chi^{2}$ test on the results taken from the 60 square analysis shows that the drumlin distribution is random. This conclusion is also illustrated by the fact that the number of drumlins per square varies from zero to six.

As most of the drumlins measured in the 60 square test are onshore or in offshore areas which have not been subjected to extensive erosion, the reason for the low density remains obscure but it may be related to the nature of the bedrock, the composition of the drumlins or - as will be seen in the discussion-by removal by ice flowing in a different direction.

\section{COMPOSITION OF THE DRUMLINS}

Many of the eroded drumlin islands were examined and in all cases it was found that the drumlins are composed of massive till containing large blocks of local bedrock. No evidence of rock cores was found in any of the exposures.

At the top of the south end of Lear Island (Fig. I) a lens of contorted silt and fine sand was found which measured about $1.5 \mathrm{~m}$ thick and $30 \mathrm{~m}$ in length. At the south-east end of the island this lens of stratified material interfingers with the till which indicates that the silt lens was deposited during the last stages of drumlin development.

Granulometric analyses were made on $3 \mathrm{~kg}$ samples of till taken from Robins Head, Lear and Reef Islands (Fig. I). The analysis was carried out by first sieving the entire sample through a $2 \mathrm{~mm}$ opening screen to gain some knowledge of the amount of gravel present. The material passing the $2 \mathrm{~mm}$ sieve was split down into $\mathrm{roo} \mathrm{g}$ samples for sand, silt and clay 
determination. The first analysis to determine the amount of gravel present shows that for Reef Island gravel accounts for about $20 \%$ of the total, Robins Head 25-32\% and Lear Island $33 \%$. The results of the analysis in the minus $2 \mathrm{~mm}$ size fraction are shown in Table I.

Table I. Granulometric analysis of till

\begin{tabular}{lccc}
\multicolumn{1}{c}{ Location } & $\%$ & $\%$ & $\%$ \\
Reef Island & $-2 m m+63 \mu m$ & $-63 \mu m+2 \mu m$ & $<2 \mu m$ \\
Robins Head & 40.6 & 57.6 & 1.2 \\
Robins Head & 58.5 & 35.3 & 5.2 \\
Lear Island & 68.7 & 30.8 & 1.5 \\
& $49 . \mathrm{I}$ & 48.6 & 2.3
\end{tabular}

Granulometric analyses of the "c" horizon or parent material of the soil developed on the three drumlins mentioned in Table I have been reported by the Nova Scotia Soil Survey (Hilchey and others, I 960 , p. 45) and the results show that the clay content varies from 0.2 to $\mathrm{I} .4 \%$, which is in reasonable agreement with the results shown in Table I.

In summary, the drumlins are composed of till which is rich in gravel, sand and silt and only minor amounts of clay. The till between the drumlins is also composed of coarse material (Hilchey and others, r96o, p. 45).

The pebble lithology of the till in the Yarmouth area has been studied by Grant (unpublished). This comprehensive study shows that in the Yarmouth area the pebbles in the till are composed primarily $(>90 \%)$ of rocks of the Meguma Group with minor amounts of granite, red sandstone and basalt. The basalt and red sedimentary rocks were derived from the area at least $50 \mathrm{~km}$ north of Yarmouth while those of the Meguma Group are local in origin.

In the present study an examination of the pebbles which were used for fabric analysis as well as those from the $+2 \mathrm{~mm}$ fraction from the granulometric analysis showed that all of the pebbles used for fabric measurements (about 70 pebbles per sample) were locally derived from rocks of the Meguma Group. Over $95 \%$ of the pebbles obtained from the granulometric analysis were of local origin and the remainder consisted of minor amounts of granite, jasper, quartz fragments and very small pieces of red sandstone. None of the material could be confidently defined as having originated from the area north of Yarmouth but it is likely that the jasper, granite and small pieces of red sandstone were derived from a northern source.

\section{FABRIC ANALYSIS}

Fabric analyses were performed by digging pits in the fresh till faces on the south end of three drumlins (Robins Head, Lear and Reef Islands; Fig. I). About 12 pits were dug, each exposing a horizontal surface measuring I $\mathrm{m}$ by $0.7 \mathrm{~m}$. Eight of these pits were located $2.5 \mathrm{~m}$ below the surface of the drumlins and four 6-8 $\mathrm{m}$ below the surface. The inclination and declination of the long axis of 6o-8o pebbles was measured from each pit. The results show that the fabric analysis carried out in the pits $6-8 \mathrm{~m}$ below the surface did not have welldefined peaks. The results of the fabric analysis from the pits $2.5 \mathrm{~m}$ below the surface are shown in Figures 2 and 3.

Figure 2 shows the two-dimensional orientation as rose diagrams and Figure 3 shows the three-dimensional orientations. It is noted that in all cases the fabric analyses which were made near the central axes of the drumlins showed that the long axes of the pebbles are statistically orientated parallel to the long axes of the drumlins involved and the plunge is to the north. In the case of Reef Island, the western half of the drumlin has been removed by erosion and diagrams IC (Fig. 2) and ID (Fig. 3) represent fabric analysis on the central axes of the drumlins. In other cases where the pits were dug on the south-west and south-east faces of the drumlins the long axes of the pebbles are statistically orientated at an angle of 
THE YARMOUTH DRUMLIN FIELD, NOVA SCOTIA, CANADA
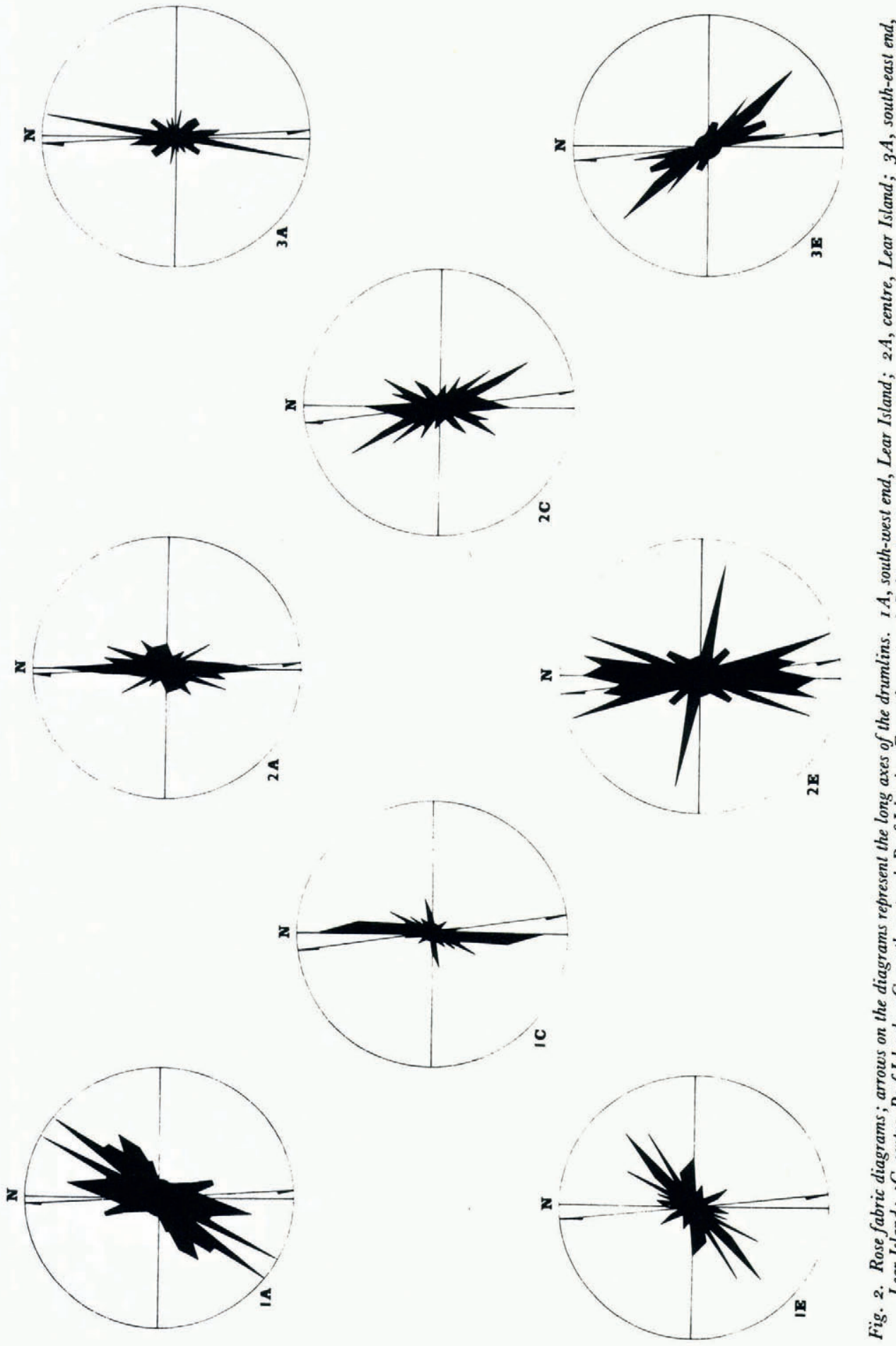

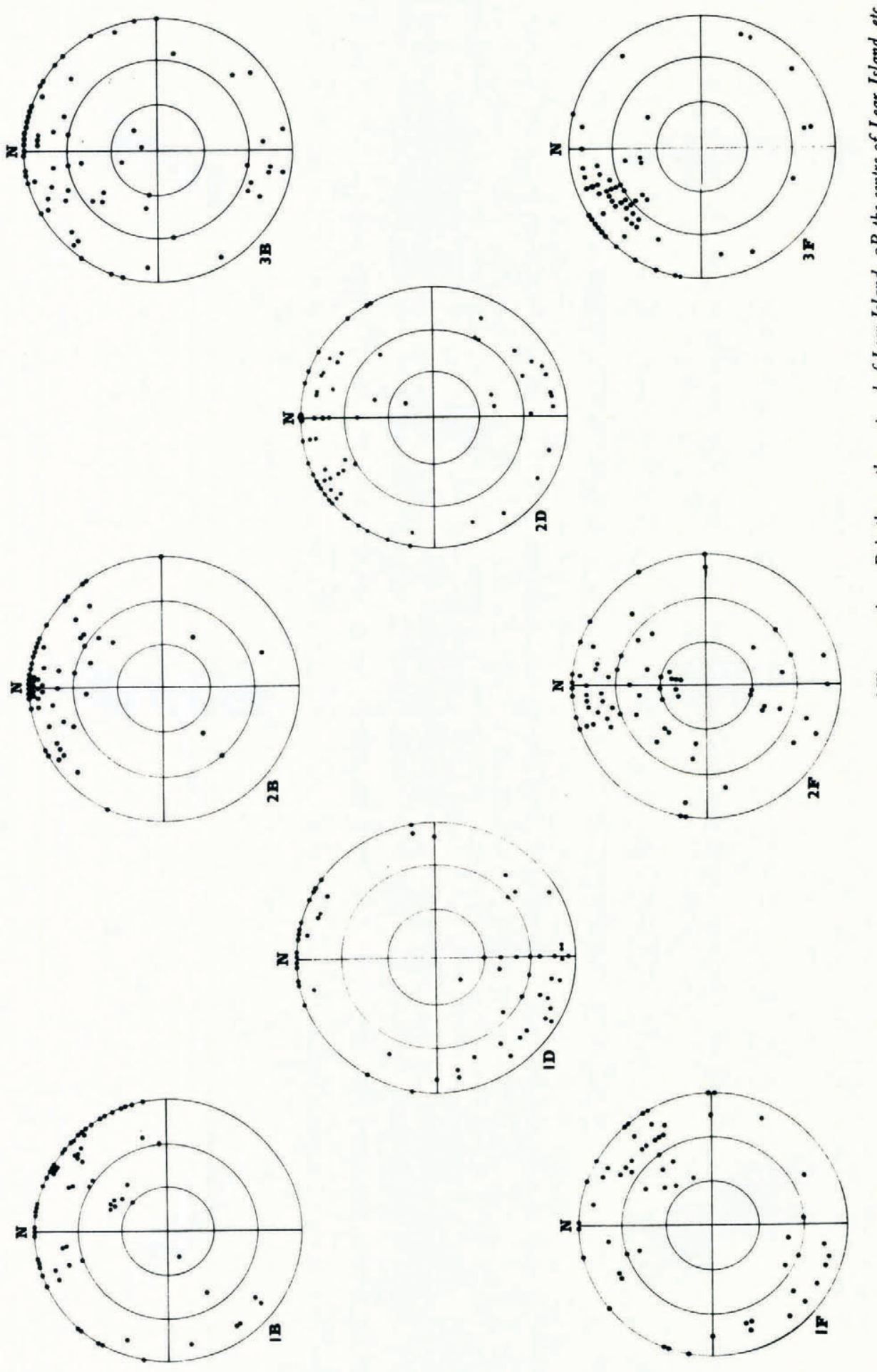
from $20^{\circ}$ to $50^{\circ}$ away from the direction of the long axes of the drumlins and form a herringbone pattern. The one exception to this pattern is the fabric found on the south-east end of Lear Island (Fig. 2, 3A; Fig. 3, 3B). This particular fabric is suspect, however, as the till at this location is particularly stony and the pit is close to the contorted sand and silt lens mentioned above. It is noted that in all cases except one (Fig. 3, ID) there is a moderate to positive plunge of the long axes of the pebbles to the north.

\section{ShaPE OF THE DRUMLINS}

After the field work had started on the fabric analyses it was discovered that the stoss end of most of the island drumlins was at the southern end of the islands and the islands tapered to the north (unless otherwise specified, the word "stoss" is used to mean the more steeply inclined wider end of the drumlin and the high point on the drumlin is closer to the steep end than to the more shallowly inclined tapered "tail" of the drumlin). At first it was thought that this was due to wave and tidal erosion but an examination of the inland drumlins quickly confirmed that most of these had the typical drumlin "egg" shape with the stoss end at the south end of the drumlins. At this point each drumlin in the field was examined on air photographs and the shape recorded in one of three categories: first, those with the stoss end clearly positioned on the southern end of the drumlins and the taper to the north; second, those of elliptical shape where it was not possible to define the stoss end at the north or south; and third, those with the stoss end at the northern extremity of the drumlin. The results are shown on Figure $\mathrm{I}$. Of the $\mathrm{I}_{5} \mathrm{I}$ drumlins identified, $83(55 \%)$ fall in the first category, $65(43 \%)$ in the second and $3(2 \%)$ in the third.

In order to examine further the shape of the drumlins, alternate lines of air photographs were examined and the length and breadth of 50 drumlins was measured. From these values, Chorley $k$ values (Chorley, 1959) were determined from a nomogram devised by Smalley and Unwin (1968, p. 382). Each of the drumlins was identified as belonging to category $\mathrm{I}$ or 2 above. As it turned out, there were 25 in each category and the mean $k$ value for those with the stoss end to the south was 2.3 and those of elliptical shape 2.7. The values are below the mean reported for other drumlin fields (Smalley and Unwin, r968, p. 383; Doornkamp and King, I97 I, p. 301) and indicate that the drumlins are highly tapered and show a broad and well-defined stoss end in plan view. In contrast, drumlins with high $k$ values are indicative of a more elongate elliptical pattern (Chorley, r959, p. 344). Doornkamp and King (I97 I, p. 302) interpreted the variations in $k$ values to mean that large $k$ values are indicative of a constant direction of ice flow over a long period of time and small $k$ values-approaching a spherical shape - are indicative of variable flow and lack of constancy in a given flow direction. This explanation may be somewhat oversimplified in that it does not take into account the nature of the material which makes up the drumlins. For example, it may take a much shorter period and constancy of flow to mold clay-rich drumlins into elongate shapes, whereas coarse materials may offer much more resistance to the molding mechanism. To the writer's knowledge, no attempt has been made to relate $k$ values to granulometric analyses and this should be done over a number of drumlin fields to determine if there is any correlation between the two.

\section{SHAPE OF DRUMLINS IN OTHER FIELDS}

It is generally taken for granted that the stoss end of drumlins points towards the upstream ice-movement direction. The acceptance of this general observation is critical in deciphering the ice-movement directions in the Yarmouth area. It is important therefore to demonstrate that similar patterns of shapes exist in other drumlin fields where the icemovement direction is known. In each of the cases mentioned below the stoss end of the drumlins points up-stream. 
In an analysis of the morphology of the drumlins in the Dollard field, Saskatchewan, Kupsch (1955, p. $3^{29}$ ) reported "Slopes as much as $30^{\circ}$, but generally $15^{\circ}$ to $20^{\circ}$ were observed for the stoss side, whereas the lee side showed slopes as low as $6^{\circ}$ ". In addition, Kupsch (1955, p. 331) showed a plan and profile view of one of the drumlins which clearly indicates that the high point on the drumlin is close to the stoss end.

Chorley (1959, p. 343, fig. 6) showed the basal outlines and high points of a selection of drumlins representative of those formed by the Green Bay Glacier in Wisconsin (taken from Alden, 1905). Of the 76 plan views shown, 64 have crosses marking the high point on the drumlin. Of these 64,42 show the high point closest to the stoss end, 18 show the high point near the centre of the drumlin end and in four instances the high point is closer to the tail end. In addition, Chorley ( 1959 , p. 344) fitted lemiscate loops to 23 of the drumlins and in all cases the best fit clearly showed that the broad end of the drumlin points up-stream.

In a study of the Peterborough drumlin field in Ontario, Heidenreich (1964, p. 103) showed the plan view and contours of about 21 drumlins. Of these 21 shapes, 19 show steep and broad stoss ends and the high point is close to the stoss end. The remaining two are elliptical and none reversed. It is known, however, that some of the drumlins in the Peterborough field are reversed (Gravenor, I 957, p. 20). In order to determine the relative number of reversals in profile of the drumlins in the Peterborough field, a study was made on the drumlins south-east of the city of Peterborough using air photographs. Of 145 drumlins examined, 95 are elliptical in shape - some approaching the shape of a fluting - and have no well-defined stoss or lee end, 44 are "normal" in the sense that they have a steep broad stoss end and six have a reversed profile.

From this study, it is evident that if the shapes of a reasonable number of drumlins from a given drumlin field are examined, the ice direction can be determined.

\section{Discussion}

In the Yarmouth area, the pebble lithology (Grant, unpublished) provides strong evidence that some components of the till were derived from a northern source. While this fact must be accepted, it is difficult to reconcile with the shape of the drumlins which suggests a north to north-west direction of ice movement. It is true that in some drumlin fields an occasional drumlin may have a reversed profile but it is impossible that over $50 \%$ of the drumlins would be reversed and only $2 \%$ show a "normal" profile. As an added complication to this problem, however, it is noted that most of the pebble fabrics show a moderate to strong plunge to the north. This anomaly may be a result of the fact that all the measurements were made on the south (stoss) end of the drumlins and further studies should be made along the long axes of the drumlins. In addition, the Yarmouth drumlin field appears to be atypical with respect to the density of the drumlins, their shape and granulometric composition. It is quite possible that the low density may be related to the nature of the bedrock in that it is noted that no drumlins are found over areas underlain by granite. The low Chorley $k$ values may be related to a short duration of ice flow in a given direction or to the lack of clay and preponderance of coarse material in the till which was derived from local bedrock. Perhaps unique subglacial conditions produced reversed drumlin shapes in the Yarmouth area but an alternative explanation is suggested below.

The ice-movement direction of the last glaciation in Nova Scotia is complex, and, as explained by Prest and Grant (1969), this complexity is probably related to a prolonged period of late, active ice flow from local centres in the Maritimes. They concluded that local ice caps may have formed in some Maritime areas prior to the advance of the continental ice sheet and that during glacier recession local ice activity was resumed with ice flow in diverse directions. 
If it is accepted that the main continental ice flow was from the north-west and terminated some distance into the present Atlantic Ocean south of the Yarmouth area (Prest and Grant, r 969 , p. 5), then during this period when sea-levels were low the glacier would be grounded on the shelf south of the Yarmouth area. The terminal zone of the glacier would then form a topographic high which, bordering the ocean, would provide an area of excessive accumulation analogous to the situation which Prest and Grant (1969) postulated for the uplands of south-western Nova Scotia and elsewhere in the Maritimes. Under these conditions, there could have been a short period when the ice reversed its direction of flow until the continuing rise of sea-level dissipated the ice. The observed drumlin shapes may thus be the result of south to south-easterly flowing ice followed by a reversed flow during a late phase of glaciation. The original ice flow from the north would explain the presence of "northern" pebbles in the till and the change in ice-flow direction would serve to explain the shape of the drumlins and help to account for the low drumlin density in that some pre-existing drumlins might have been removed by ice flowing from the south.

Finally, it is of interest to note that the concept of an ice dome forming on the continental shelf south of Nova Scotia is not new. Grant (I97I[a], [b]) has described similar sets of circumstances in Cape Breton Island where there is strong evidence to suggest that a northerly ice flow in that area resulted from an ice dome on the continental shelf.

\section{Conclusions}

An analysis of the shapes of the drumlins of the Yarmouth field suggests that the ice that shaped the drumlins came from the south. This analysis is inconsistent with the pebble lithology of the tills of the area which indicates that ice moved across the Yarmouth area from the north. One possible explanation for this phenomenon is that a local ice centre developed on the continental shelf, south of the Yarmouth area, during an early phase of continental deglaciation, and for a brief period there was a flow of this ice north across the Yarmouth area. This conclusion is in harmony with the shape analysis of the drumlins and it is in keeping with similar suggestions to account for the north flow of ice on the Atlantic side of Cape Breton Island.

\section{ACKNOWLEDGEMENTS}

This study of the Yarmouth drumlin field was made possible by a grant-in-aid of research from the Geological Survey of Canada. The author would like to thank V. K. Prest and D. R. Grant of the Geological Survey of Canada for their helpful suggestions and comments during the course of the study.

MS. received 26 April 1973

\section{REFERENCES}

Alden, W. C. 1905. The drumlins of southeastern Wisconsin. U.S. Geological Survey. Bulletin No. 273, p. 9-46.

Chorley, R. J. 1959. The shape of drumlins. Journal of Glaciology, Vol. 3, No. 25, p. 339-44.

Doornkamp, J. C., and King, C. A. M. 1971. Numerical analysis in geomorphology: an introduction. London, Edward Arnold (Publishers) Ltd.

Goldthwait, J. W. 1924. Physiography of Nova Scotia. Canada. Geological Survey. Memoir 140.

Grant, D. R. 1971[a]. Glaciation of Cape Breton Island, Nova Scotia. Canada. Geological Survey. Paper 71-1, Pt. B, p. $118-20$.

Grant, D. R. 197 r [b]. Surficial geology, southwest Cape Breton Island, Nova Scotia. Canada. Geological Survey. Paper 71-1, Pt. A, p. 161-64.

Grant, D. R. 1972. Surficial geology of southeast Cape Breton Island, Nova Scotia. Canada. Geological Survev. Paper 72-1, Pt. A, p. 160-63.

Grant, D. R. Unpublished. Pebble lithology of the tills of southeast Nova Scotia. [M.Sc. thesis, Dalhousie University, Halifax, 1963.] 
Gravenor, C. P. 1957. Surficial geology of the Lindsay-Peterborough area, Ontario, Victoria, Peterborough. Durham and Northumberland Counties, Ontario. Canada. Geological Survey. Memoir 288.

Heidenreich, C. 1964 . Some observations on the shape of drumlins. Canadian Geographer, Vol. 8, No. 2, p. Ior-07. Hilchey, J. D., and others. 1960. Soil survey of Yarmouth County, by J. D. Hilchey, D. B. Cann and J. I. Macdougall. Nova Scotia Soil Survey. Report 9.

Kupsch, W. O. 1955. Drumlins with jointed boulders near Dollard, Saskatchewan, Canada. Bulletin of the Geological Society of America, Vol. 66, No. 3, p. 327-37.

Prest, V. K., and Grant, D. R. 1969. Retreat of the last ice sheet from the Maritime Provinces. Gulf of St. Lawrence region. Canada. Geological Survey. Paper 69-33.

Smalley, I. J., and Unwin, D. J. 1968. The formation and shape of drumlins and their distribution and orientation in drumlin fields. Journal of Glaciology, Vol. 7, No. 51, p. 377-90.

Taylor, F. C. r 967 . Reconnaissance geology of Shelburne map-area, Queens, Shelburne and Yarmouth Counties, Nova Scotia. Canada. Geological Survey. Memoir 349.

IVilson, J. T. 1938. Drumlins of southwest Nova Scotia. Transactions of the Royal Sociely of Canada, Third Series, Sect. 4, Vol. 32, p. 41-47. 